Revista de la red interuniversitaria de estudios sobre las literaturas rioplatenses contemporáneas en Francia

$18 \mid 2018$

El río y la ciudad

\title{
La pregunta heracliteana
}

\section{Miguel Ángel Petrecca}

\section{OpenEdition}

Journals

Edición electrónica

URL: http://journals.openedition.org/lirico/5667

DOI: $10.4000 /$ lirico.5667

ISSN: 2262-8339

Editor

Réseau interuniversitaire d'étude des littératures contemporaines du Río de la Plata

\section{Referencia electrónica}

Miguel Ángel Petrecca, «La pregunta heracliteana », Cuadernos LIRICO [En línea], 18| 2018, Puesto en línea el 13 octubre 2018, consultado el 21 abril 2019. URL : http://journals.openedition.org/lirico/5667 ; DOI : 10.4000/lirico.5667

Este documento fue generado automáticamente el 21 abril 2019.

\section{(c) (i) (9)}

Cuadernos LIRICO está distribuido bajo una Licencia Creative Commons Atribución-NoComercialSinDerivar 4.0 Internacional. 


\title{
La pregunta heracliteana
}

\author{
Miguel Ángel Petrecca
}

¿Hay río en Berlín? Es la pregunta que se hace el escritor Fabio Morábito en una de las primeras páginas de su libro Berlín también se olvida, producto de una estadía de un año en la capital alemana: "Después de tres meses de vivir en Berlín y de recorrerlo en metro, en S-Bahn, en autobús y tranvía," dice Morábito, "todavía no puedo decir si esta ciudad tiene un río o no". La pregunta es menos inocente de lo que parece y va mucho más allá de la respuesta literal que llevaría a decir, como Morábito de hecho no ignora, ya que incluso lo ha visto en un documental antes de viajar, que en Berlín hay un río que se llama Spree. No sólo hay un río, sino que ese río atraviesa la ciudad y la gente atraviesa el río a través de puentes e islas. Y sin embargo, Morábito insiste. "Cuando en el documental sobre Berlín vi los barcos turísticos que iban y venían por el Spree, no dudé de que Berlín tuviera un río. Pero ahora, después de tres meses de vivir en Berlín, empiezo a dudarlo". Morábito encuentra poco después, en la conversación con un amigo, la respuesta a esta paradoja o a esta sensación de no poder nombrar como río el agua que cruza la ciudad: es que el agua del Spree está inmóvil. No corre. "El berlinés", dice Morábito, "no tiene la experiencia heracliteana de la corriente". El texto de Morábito tiene la virtud, para mí, de poner en cuestión la idea de río, o la idea del río en relación con la ciudad. No todo río es un río, nos dice Morábito, o mejor, existiría un modelo prototípico de la relación entre el río y la ciudad, y de acuerdo a la adecuación o no a ese modelo (al modero heracliteano) podríamos juzgar si una ciudad tiene o no tiene río. Si en el caso de Berlín la ciudad no se adecua del todo a ese modelo, en el de Buenos Aires la lejanía o la inadecuación sería mucho más evidente. A la pregunta acerca de si hay río en Buenos Aires, la respuesta sería un tajante no. Hay río alrededor, hay río debajo de Buenos Aires, pero no hay un río en Buenos Aires, lo cual no significa, por otro lado, que la experiencia heracliteana esté ausente. A falta de río, está el tren, como bien señalan los versos de Fabián Casas.

El hombre de campo mira pasar el río.

El hombre de ciudad mira pasar el tren.

Aunque el poema no lo aclara, y aunque en Buenos Aires hay unas cinco o seis líneas de ferrocarril entre las que uno podría en teoría elegir para imaginar la escena, para mí estos versos están situados en un lugar muy concreto de la ciudad. Me refiero a la línea Sarmiento y a los tramos de esa línea en los que la traza, que desciende bajo el nivel de la 
ciudad, se asemeja al lecho de un río y da lugar a la aparición de puentes que habilitan el gesto que la escena supone: el de alguien que, apoyado contra una baranda, mira algo que transcurre más abajo. Si lo pienso bien, sin embargo, la dicotomía que plantean los versos de Casas resulta falsa. Si pienso, por ejemplo, en la ciudad en la que escribo esto, una ciudad que, a diferencia de Berlín o de Buenos Aires, no admite ninguna duda frente a la pregunta que plantea Morábito. París tiene un río, eso está claro, ergo una experiencia heracliteana, y por eso leídos desde París los versos de Casas se vuelven falsos, o revelan, mejor dicho, a la distancia, su carácter situado, su falsa universalidad. Bajo la aparente solvencia de una máxima general, Casas dice en realidad algo que remite a una experiencia específica, local. De hecho, podría decirse que este carácter situado tal vez no sólo remite a Buenos Aires sino a toda la Argentina, porque hasta donde sé, o hasta donde recuerdo, o hasta donde puedo inferir a partir de imágenes propias y prestadas, en Argentina no hay ciudades con río. Cada vez que intento aplicar a una ciudad argentina la pregunta de Morábito (la pregunta heracliteana), los reparos no tardan en surgir y la negativa se impone. Rosario, por ejemplo, ¿tiene o no tiene río? De nuevo, algunos podrían sentirse tentados a decir que sí tiene río, y sin duda tiene más río que Buenos Aires, pero al mismo tiempo, pensando en nuestro modelo heracliteano de relación ciudad-río, da la sensación de que algo falta. En Rosario, al fin, como en Buenos Aires, el río es una frontera, pasada la cual se cambia no sólo de ciudad sino de provincia. ¿Y Córdoba? ¿Córdoba, tiene o no tiene río? La repuesta aquí también es negativa, y por las razones opuestas, porque a nadie se le ocurriría seriamente postular a la categoría de río esa hilacha que los cordobeses (¿o también los mapas?) llaman la Cañada, y lo mismo vale para el caso de Bahía Blanca y el Napostá. De esa forma, como se ve, la relación entre el río y la ciudad, en Argentina, oscila entre dos extremos, entre dos puntos que se alejan igualmente, por desmesura en un caso y por pequeñez en el otro, del modelo heracliteano, del modelo parisino si se quiere. Esta tipología está tan arraigada que, incluso en el único caso en que, se me ocurre, la escala hubiera permitido la implantación de un modelo heracliteano, como es el caso del Río Negro en el punto en que desemboca en la provincia de Buenos Aires, el hábito urbanístico hizo que, en lugar de la creación de una ciudad dividida por un río heracliteano, se crearan dos ciudades, separadas por un río que, una vez más, funciona como frontera entre dos ciudades y dos provincias: Carmen de Patagones y Viedma, Río Negro y Buenos Aires. ¿No es significativo que este haya sido justamente el lugar elegido por Alfonsín para trasladar la capital? ¿En la elección de esas ciudades no jugaba también, inconscientemente, el deseo de reparar también otra falta, matando dos pájaros de un tiro? Lo que quiero decir es que si el proyecto de la mudanza se hubiera concretado, si las dos ciudades se hubieran convertido en una sola, habríamos tenido quizás por primera vez una ciudad con río. 